\title{
Perubahan Berat Organ Hati, Ginjal, Limfa, Otak, Lambung, Testis, Jantung dan Paru-paru Mencit yang Diberi Ekstrak Batang Sipatah-patah (Cissus quadrangula Salisb.)
}

\author{
Changes in the Weight of Liver Organ, Kidney, Lymph, Brain, Stomach, \\ Testicles, Heart and Lungs Mice Given A Cissus quadrangula Salisb. Stem \\ Extract

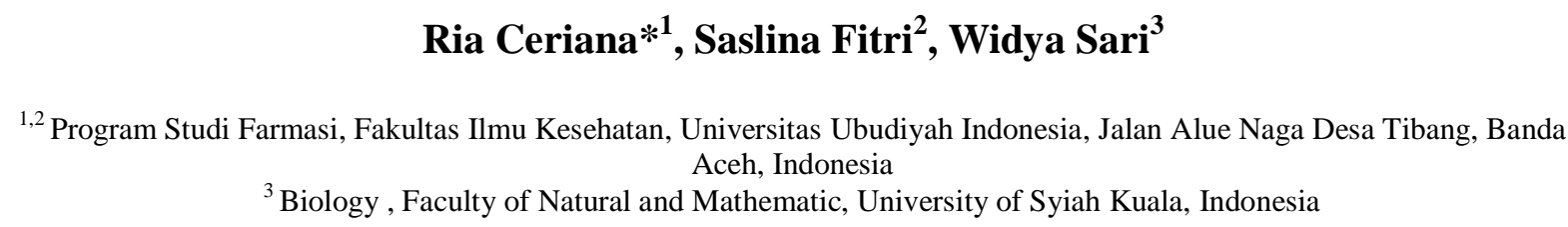

\begin{abstract}
Abstrak
Masyarakat Aceh telah lama menggunakan tumbuh-tumbuhan sebagai obat-obatan. Tumbuhan-tumbuhan tersebut digunakan untuk berbagai penyakit seperti sakit perut, demam, batuk, patah tulang dan lain sebagainya. Penelitian ini bertujuan untuk mengetahui efek toksik melalui berat organ hati, ginjal, limpa dan otak mencit yang diberikan ekstrak batang Sipatahpatah. Penelitian ini menggunakan Rancangan Acak Lengkap (RAL). Penelitian ini menggunakan empat perlakuan dan lima ulangan. Perlakuan berupa empat tingkatan dosis ekstrak batang Sipatah-patah yaitu $0 \mathrm{mg} / \mathrm{kgbb}, 750 \mathrm{mg} / \mathrm{kgbb}, 1500 \mathrm{mg} / \mathrm{kgbb}$ dan 3000 $\mathrm{mg} / \mathrm{kgbb}$. Data dianalisis menggunakan analisis varian (ANAVA) yang diuji lanjut dengan uji lanjut Duncan taraf keprcayaan 95\% apabila berpengaruh terhadap perlakuan. Hasil penelitian ini ialah ekstrak batang Sipatah-patah berpengaruh terhadap berat organ hati dan limpa tetapi tidak pada organ ginjal dan otak.
\end{abstract}

Kata Kunci: Sipatah-patah, Cissus quadrangula Salisb., hati, ginjal, limpa, otak

\begin{abstract}
The Acehnese have long used plants as medicines. These plants are used for various diseases such as abdominal pain, fever, cough, broken bones and so forth. This study aims to determine the toxic effects through the weight of the liver, kidneys, spleen and brain of mice given the extract of Sipatah-patah stem. This study uses a Completely Randomized Design (CRD). This study used four treatments and five replications. Treatments were four levels of Sipatah-patah stem extract, namely $0 \mathrm{mg} / \mathrm{kg}$ body weight, $750 \mathrm{mg} / \mathrm{kg}$ body weight, $1500 \mathrm{mg}$ / $\mathrm{kg}$ body weight and $3000 \mathrm{mg} / \mathrm{kg}$ body weight. Data were analyzed using analysis of Variance (ANOVA) which was tested further with Duncan's advanced test $95 \%$ confidence level. The results of this study were Sipatah-patah stem extract affecting the weight of the liver and spleen but not in the kidneys and brain.
\end{abstract}


Keywords: Sipatah-patah, Cissus quadrangula Salisb., liver, kidney, spleen, brain PENDAHULUAN

Masyarakat Aceh telah lama menggunakan tumbuh-tumbuhan sebagai obat-obatan. Tumbuhan-tumbuhan tersebut digunakan untuk berbagai penyakit seperti sakit perut, demam, batuk, patah tulang dan lain sebagainya. Tumbuhan yang secara empiris terbukti digunakan oleh masyarakat Aceh sebagai obat yaitu batang Sipatah-patah (Cissus quadrangula Salisb.). Tumbuhan ini digunakan sebagai obat patah tulang. Berdasarkan laporan Sabri dkk, (2009), tumbuhan ini dipakai untuk menyembuhkan penyakit rematik dan patah tulang dengan cara merebus dengan unsur-unsur lainnya. Ekstrak batang Sipatah-patah varietas lainnya di India ternyata memiliki aktivitas antiartritik yang dapat mengurangi peradangan pada rematik (Senthamari et al., 2013).

Laporan Deka et al., (1994) juga menyebutkan bahwa ekstrak batang Sipatah-patah dapat menyembuhkan tulang radius ulna pada anjing. Hal tersebut dikarena kandungan kalsium dan fitoestrogen yang tinggi pada ekstrak batang Sipatah-patah (Sabri dkk., 2009). Kalsium merupakan salah satu mineral mikro yang sangat dibutuhkan oleh tubuh. Kekurangan asupan zat ini dapat menyebabkan osteoporosis terutama untuk wanita. Ekstrak batang Sipatah-patah sangat membantu dalam proses pertumbuhan tulang dan pertahanan massa tulang. Menurut Djuwita dkk., (2012), ekstrak batang Sipatah-patah dapat membantu proses osteogenesis dengan terjadinya proliferasi dan diferensiasi sel tulang. Hasil penelitian Ceriana dkk.,(2014) semakin memperkuat bahwa ekstrak batang Sipatah-patah memang berpotensi dalam menumbuhkan sel tulang karena ekstrak ini dapat menginduksi stem cell untuk berproliferasi dan berdiferensiasi menjadi sel tulang. Jadi, dapat disimpulkan bahwa ekstrak batang Sipatah-patah dapat mengobati penyakit degeneratif seperti osteoporosis. Sabri dkk., (2011) menyatakan bahwa ekstrak batang Sipatah-patah dapat membantu pertumbuhan tulang pada mencit betina normal.

Ekstrak batang Sipatah-patah dapat dijadikan sebagai obat komersila dengan melalui tahapan uji toksisitas. Uji toksisitas telah dilakukan secara makroskopis (Ceriana dan Sari 2016) dan mikroskopis pada hati dan ginjal mencit (Sari dkk., 2017). Namun demikian, belum diketahui efek pemberian ekstrak batang Sipatah-patah pada berat berbagai organ tubuh seperti hati, ginjal, limfa, otak. 


\section{METODE PENELITIAN}

\section{Tempat dan Waktu Penelitian}

Penelitian ini dilakukan di Laboratorium Mikroteknik Jurusan Biologi FMIPA Universitas Syiah Kuala, Banda Aceh dari bulan Agustus sampai November 2015.

\section{Alat dan Bahan}

Alat-alat yang digunakan dalam penelitian ini yaitu kandang mencit yang diberi kawat jarring, pipet tetes, alat tulis, timbangan analitik, kamera digital, alat bedah, sonde lambung mencit, baki bedah, gelas beaker, rotary vacuum evaporator, waterbath.

Bahan-bahan yang digunakan dalam penelitian ini yaitu mencit jantan berumur 2 bulan, batang Sipatah-patah (Cissus quadrangula Salisb.), pellet jenis 789-S, kapas, akuades, larutan $\mathrm{NaCl}$ fisiologis, sarung tangan dan masker.

\section{Rancangan Penelitian}

Penelitian ini menggunakan Rancangan Acak Lengkap (RAL). Penelitian ini menggunakan empat perlakuan dan lima ulangan. Perlakuan berupa empat tingkatan dosis ekstrak batang Sipatah-patah yaitu $0 \mathrm{mg} / \mathrm{kgbb}, 750 \mathrm{mg} / \mathrm{kgbb}, 1500 \mathrm{mg} / \mathrm{kgbb}$ dan 3000 $\mathrm{mg} / \mathrm{kgbb}$.

\section{Prosedur Kerja}

a. Preparasi Sampel Tumbuhan

Sampel tumbuhan batang Sipatah-patah diperoleh di daerah kawasan Ujung Batee, Aceh Besar. Sampel yang diambil yaitu bagian batang yang masih muda dan segar.

b. Pembuatan Ekstrak Batang Sipatah-patah

Batang Sipatah-patah dipotong-potong sepanjang sekitar $1 \mathrm{~cm}$, selanjutnya dikering anginkan pada suhu kamar sampai kering. Setelah kering, simplisia direndam dalam wadah tertutup dengan menggunakan etanol 95\%. Simplisia tersebut direndam selama 2 x 24 jam dan sesekali diaduk. Setelah itu, larutan disaring sehingga menghasilkan maserat dan disaring kembali dengan kertas saring akan memperoleh filtrat. Simplisia direndam kembali dengan etanol 95\% dan disaring lagi. Filtrat 1 dan filtrat 2 yang telah diperoleh disatukan dan dilanjutkan dengan pemekatan menggunakan alat rotary vacuum evaporator. 
Setelah didapatkan ekstrak kental, maka ekstrak dibebas etanolkan dengan menggunakan waterbath. Ekstrak selanjutnya disimpan dalam wadah tertutup rapat dan disimpan dalam kulkas.

c. Penyediaan Hewan Coba

Mencit sebagai hewan coba diperoleh dari vivarium Jurusan Biologi FMIPA Unsyiah. Penelitian ini menggunakan 20 ekor mencit jantan (Mus musculus L.) galur Swiss Webster berumur 2 bulan dengan berat badan antara 20-25 g. Hewan diaklimatisasi selama 7 hari di dalam kandang berukuran $48 \mathrm{~cm}$ x $36 \mathrm{~cm}$ x $13 \mathrm{~cm}$ yang dialasi sekam dan ditutup jarring kawat. Mencit diberi makan dan minum secara ad libitum.

d. Perlakuan Ekstrak Batang Sipatah-patah terhadap Mencit

Ekstrak terlebih dahulu dibuat suspensi dan larutan stok sesuai dosis dengan menggunakan pelarut. Hewan coba yang diaklimatisasi dipisahkan untuk diberi ekstrak batang Sipatah-patah. Suspensi ekstrak diberikan sebanyak $1 \mathrm{ml}$ menggunakan sonde lambung mencit. Suspeni diberikan setiap hari selama 2 minggu (14 hari) pada pukul 12.00 WIB setelah dipuasakan terlebih dahulu selama 12-16 jam. Selanjutnya makanan diberikan kembali setelah 6 jam pemberian ekstrak.

e. Pengambilan Organ

Mencit dikorbankan pada hari ke 15 dengan cara dibius dan dibedah untuk diambil organ hati, ginjal, limfa, otak. Organ tersebut dicuci menggunakan $\mathrm{NaCl}$ fisiologis lalu ditimbang dengan timbangan analitik dan dicatat.

f. Parameter Penelitian

Parameter yang diamati dalam penelitian ini ialah berat organ hati, ginjal, limpa dan otak.

\section{Analisis Data}

Data yang telah diperoleh dianalisis secara statistik dengan menggunakan Analisis Varian (ANAVA). Apabila terdapat pengaruh perlakuan maka akan diuji lanjut menggunakan uji lanjut Duncan dengan taraf kepercayaan 95\%.

\section{HASIL DAN PEMBAHASAN}


Data berat semua organ yaitu hati, ginjal, limpa dan otak yang telah didapatkan selama penelitian dianalisis secara statistik dengan menggunakan ANAVA. Hal tersebut dilakukan untuk mengetahui pengaruh perlakuan ekstrak batang Sipatah-patah terhadap berbagai berat organ pada mencit. Hasil data penelitian berat organ hati dapat dilihat pada Tabel 1.

Tabel 1. Rata-rata berat organ hati yang diberi perlakuan ekstrak batang Sipatah-patah

\begin{tabular}{ccc}
\hline No. & Perlakuan & Rata-rata Berat Organ Hati \pm SD \\
\hline 1 & Kontrol (P0) & $1,42 \pm 0,06^{\mathrm{a}}$ \\
2. & $750 \mathrm{mg} / \mathrm{kgbb}(\mathrm{P} 1)$ & $1,60 \pm 0,08^{\mathrm{b}}$ \\
3. & $1500 \mathrm{mg} / \mathrm{kgbb}(\mathrm{P} 2)$ & $1,65 \pm 0,04^{\mathrm{b}}$ \\
4. & $3000 \mathrm{mg} / \mathrm{kgbb}(\mathrm{P} 3)$ & $1,89 \pm 0,16^{\mathrm{c}}$ \\
\hline
\end{tabular}

Keterangan: Huruf superskrip berbeda yang terdapat pada angka dalam kolom yang sama menunjukkan perlakuan saling berbeda nyata $(\operatorname{Sig}<0,05)$.

Tabel 1 menunjukkan bahwa perlakuan ekstrak batang Sipatah-patah berpengaruh terhadap berat organ hati mencit $($ Sig $<0,05)$. Setelah diuji lanjut dengan uji lanjut Duncan dihasilkan bahwa perlakuan kontrol (P0) berbeda nyata $(\mathrm{Sig}<0,05)$ dengan perlakuan dosis 750 mg/kgbb (P1), 1500 mg/kgbb (P2) dan 3000 mg/kgbb (P3). Perlakuan dosis 750 mg/kgbb tidak berbeda nyata $(\mathrm{Sig}<0,05)$ dengan dosis $1500 \mathrm{mg} / \mathrm{kgbb}$. Dosis yang paling berat organ hatinya yaitu dosis $3000 \mathrm{mg} / \mathrm{kgbb}$.

Perubahan berat organ hati tersebut sesuai dengan laporan Ceriana dan Sari (2016) bahwa organ hati terlihat lebih besar pada dosis $3000 \mathrm{mg} / \mathrm{kgbb}$ dibandingkan dengan dosis lainnya secara makroskopis. Hati merupakan organ yang penting dalam proses detoksifikasi berbagai zat asing dan toksin. Hari tersusun atas lobules-lobulus yang terdiri dari sel-sel hati yang diabtasi sinusoid. Selain itu, sel kupffer yang memfagositosis zat-zat asing yang masuk ke dalam tubuh. Sel kupffer merupakan sistem monosit-makrofag, dan berfungsi memfagositosis bakteri dan benda asing lain di dalam darah yang mengaliri hati. Sejumlah 50\% dari semua makrofag dalam darah ialah sel Kuppfer, sehingga hati merupakan salah satu organ penting dalam pertahanan melawan invasi bakteri dan toksik (Price and Wilson, 2006). Hasil penelitian untuk berat organ ginjal dapat dilihat pada Tabel 2 di bawah ini.

Tabel 2. Rata-rata berat organ ginjal mencit yang diberi perlakuan ekstrak batang Sipatahpatah

\begin{tabular}{ccc}
\hline No. & Perlakuan & Rata-rata Berat Organ Ginjal \pm SD \\
\hline 1 & Kontrol $(\mathrm{P} 0)$ & $1,44 \pm 0,08$
\end{tabular}




$\begin{array}{lcc}\text { 2. } & 750 \mathrm{mg} / \mathrm{kgbb}(\mathrm{P} 1) & 1,22 \pm 0,02 \\ \text { 3. } & 1500 \mathrm{mg} / \mathrm{kgbb}(\mathrm{P} 2) & 1,19 \pm 0,02 \\ \text { 4. } & 3000 \mathrm{mg} / \mathrm{kgbb}(\mathrm{P} 3) & 1,20 \pm 0,02\end{array}$

Tabel 2 menunjukkan bahwa tidak terdapat pengaruh perlakuan ekstrak batang Sipatah-patah terhadap berat organ ginjal pada mencit (Sig>0,05). Hal tersebut berarti pemberian ekstrak batang Sipatah-patah tidak mempengaruhi berat organ ginjal dan tidak toksik terhadap ginjal. Ginjal merupakan organ yang berperan penting di dalam tubuh. Ginjal merupakan organ sasaran toksik karena ginjal merupakan organ ekskresi yang dilewati oleh sebagian darah tubuh. Ginjal terdiri dari glomerulus yang berperan dalam memfiltrasi darah yang masuk. Selanjutnya terjadi proses absorpsi dan reabsorpsi di dalam tubulus proksimal dan distal yang berakhir pada tubulus pengumpul sehingga menjadi zat-zat yang berbahaya bagi tubuh akan diekskresikan oleh ginjal (Price and Wilson, 2006). Selanjutnya data hasil penelitian untuk berat organ limpa dapat dilihat pada Tabel 3 di bawah ini.

Tabel 3. Rata-rata berat organ limpa mencit yang diberi perlakuan ekstrak batang Sipatahpatah

\begin{tabular}{ccc}
\hline No. & Perlakuan & Rata-rata Berat Organ Limpa \pm SD \\
\hline 1 & Kontrol (P0) & $0,19 \pm 0,01^{\mathrm{c}}$ \\
2. & $750 \mathrm{mg} / \mathrm{kgbb}(\mathrm{P} 1)$ & $0,14 \pm 0,03^{\mathrm{b}}$ \\
3. & $1500 \mathrm{mg} / \mathrm{kgbb}(\mathrm{P} 2)$ & $0,08 \pm 0,02^{\mathrm{a}}$ \\
4. & $3000 \mathrm{mg} / \mathrm{kgbb}(\mathrm{P} 3)$ & $0,20 \pm 0,03^{\mathrm{c}}$ \\
\hline
\end{tabular}

Keterangan: Huruf superskrip berbeda yang terdapat pada angka dalam kolom yang sama menunjukkan perlakuan saling berbeda nyata $(\operatorname{Sig}<0,05)$

Tabel 3 menunjukkan bahwa perlakuan ekstrak batang Sipatah-patah berpengaruh terhadap rata-rata berat organ limpa $(\mathrm{Sig}<0,05)$. Data kemudian diuji lanjut menggunakan uji lanjut Duncan agar diketahui masing-masing perbedaan perlakuan. Perlakuan kontrol tidak berbeda nyata dengan perlakuan dosis $3000 \mathrm{mg} / \mathrm{kgbb}$ akan tetapi berbeda nyata $(\operatorname{Sig}<0,05)$ dengan perlakuan dosis $750 \mathrm{mg} / \mathrm{kgbb}$ dan $1500 \mathrm{mg} / \mathrm{kgbb}$. Dosis $750 \mathrm{mg} / \mathrm{kg}$ bb merupakan dosis yang menyebabkan berat organ limpa paling sedikit dan dikuti oleh dosis 1500 mg/kgbb. Jadi, ekstrak batang Sipatah-patah bersifat toksik pada organ limpa.

Limpa merupakan tempat respon imun utama yang merupakan saringan terhadap antigen asal darah. Mikroba yang terdapat di dalam darah dibersihkan makrofag dalam limpa. Limpa merupakan tempat fagosit memakan mikroba yang diikat antibodi (opsonisasi) (Bratawidjaja, 2012). Selain itu, limpa juga merupakan organ limfoid dalam tubuh yang 
memiliki fungsi filtrasi darah dan koordinasi respon imun. Limpa terdiri dari 2 bagian yaitu bagian putih dan merah. Bagian yang putih (pulpa alba) merupakan sistem kekebalan untuk melawan infeksi dan bagian yang merah (pulpa rubra) bertugas membuang bahan-bahan yang tidak diperlukan dari dalam darah seperti sel darah merah yang rusak (Guyton and Hall, 2008). Hasil penelitian berat organ otak pada mencit yang diberi ekstrak batang Sipatah-patah dapat dilihat pada Tabel 4 di bawah ini.

Tabel 4. Rata-rata berat organ otak mencit yang diberi ekstrak batang Sipatah-patah

\begin{tabular}{ccc}
\hline No. & Perlakuan & Rata-rata Berat Organ Otak \pm SD \\
\hline 1 & Kontrol (P0) & $0,39 \pm 0,02$ \\
2. & $750 \mathrm{mg} / \mathrm{kgbb}(\mathrm{P} 1)$ & $0,40 \pm 0,02$ \\
3. & $1500 \mathrm{mg} / \mathrm{kgbb}(\mathrm{P} 2)$ & $0,38 \pm 0,02$ \\
4. & $3000 \mathrm{mg} / \mathrm{kgbb}(\mathrm{P} 3)$ & $0,35 \pm 0,03$ \\
\hline
\end{tabular}

Tabel 4 menunjukkan bahwa perlakuan ekstrak batang Sipatah-patah tidak berpengaruh pada berat organ otak $(\mathrm{Sig}>0,05)$. Hal tersebut diduga karena otak memiliki sawar darah otak. Sawar darah otak ialah suatu membrane yang sangat resisten terhadap proses difusi dan memisahkan cairan intersisial darah. Pada keadaan normal terdapat dua sawar yang semipermiabel dan berfungsi melindungi otak dan medulla spinalis dari substansi yang berbahaya. Fungsi utama sawar darah otak ialah melindungi otak dari berbagai variasi substansi darah terutama senyawa toksik (Japardi, 2002).

\section{KESIMPULAN}

1. ekstrak batang Sipatah-patah berpengaruh terhadap berat organ hati dan limpa tetapi tidak pada organ ginjal dan otak.

2. Ekstrak batang Sipatah-patah aman untuk dikonsumsi apabila di bawah dosis $3000 \mathrm{mg} /$ kgbb.

\section{SARAN}

Saran dalam penelitian ini yaitu penelitian efek toksik lainnya untuk organ-organ vital yang terdapat di dalam tubuh. Selanjutnya penelitian lain mengenai berbagai bentuk sediaan ekstrak batang Sipatah-patah untuk berbagai pengobatan. 


\section{DAFTAR PUSTAKA}

Baratawidjaja, K.G. (2012). Imunologi Dasar. Edisi Ke 7, Jakarta: Gaya Baru.

Ceriana, R., Djuwita, I., Wresdiyati, T. (2014). Ekstrak Batang Sipatah-patah Meningkatkan Proliferasi dan Diferensiasi Sel Punca Mesenkimal Sumsum Tulang, Jurnal Veteriner, 15(4), 436-445.

Ceriana, R., Sari, W. (2016). Perubahan Struktur Makroskopis Hati dan Ginjal Mencit Yang Diberi Ekstrak Batang Sipatah-patah (Cissus quadrangula Salisb.), Prosiding Seminar Nasional Biotik, ISBN. 978-602-18962-9-7, 196-202.

Deka, D.K., Lahon, L.C., Saikia, J., Mukit, A. (1994). Effect of Cissus quadrangularis in Accelerating Healing Process of Experimentally Fractured Radius-Ulna of Dog: A Preliminary Study. Indian Journal of Pharmacology, 26, 44-45.

Djuwita, I., Irma A.P., Adi, W. dan Mustafa, S. (2012). Proliferasi dan Diferensiasi Sel Tulang Tikus dalam Medium Kultur In Vitro yang Mengandung Ekstrak Batang Cissus quadrangula Salisb. (Sipatah-patah), Jurnal Kedokteran Hewan Unsyiah, 6(2), 75-80.

Guyton, A.C. and Hall, J.E. (1997). Buku Ajar Fisiologi Kedokteran, Jakarta: EGC.

Japardi, I. (2002). Sawar Darah Otak, digitized by USU digital library, 1-9.

Price, L.A. dan L.M. Wilson. (2006). Patofisiologi, Jakarta: EGC.

Sabri, M., Nurhidayat, Sigit, K., Priosoeryanto, B.P., Manalu, W. (2009). Analysis of Phytochemical and Mineral Content of Sipatah-patah Plant (Cissus quadrangularis) from Aceh as Osteoporosis Premedication. Jurnal Rona Lingkungan, 2, 109-117.

Sabri, M., Nurhidayat, Sigit, K., Priosoeryanto, B.P., Manalu, W. (2011). Kualitas Tulang Tikus Betina Normal yang diberi Ekstrak Sipatah-patah pada Masa Pertumbuhan, Jurnal Veteriner, 12(2), 113-119.

Sari, W., Fitri, S., Ceriana, R., Sunarti. (2017). Efek Toksik Pemberian Ekstrak Batang Sipatah-patah (Cissus quadrangula Salisb.) Terhadap Gambaran Histologi Hati dan Ginjal Mencit, Jurnal Bioleuser, 1(1): 31-37.

Senthamari, R., Akilandeswari, S., Valarmathi. (2013). Anti Arthritic Activity of Cissus quadrangularis I and Justicia tranquebariensis in the Treatment of Rheumatism, International Journal of Pharmaceutical and Chemical Sciences, 2(3), 1435-40. 